This is a revised personal version of the text of the final journal article, which is made available for scholarly purposes only, in accordance with the journal's author permissions. The full citation is:

De la Rubia, M.A., Walker, M., Heaven, S., Banks, C.J., Borja, R. (2010) Preliminary trials of in situ ammonia stripping from source segregated domestic food waste digestate using biogas: effect of temperature and flow rate. Bioresource Technology 101(24), 9486-9492

doi:10.1016/j.biortech.2010.07.096

\title{
PRELIMINARY TRIALS OF IN SITU AMMONIA STRIPPING FROM SOURCE SEGREGATED DOMESTIC FOOD WASTE DIGESTATE USING BIOGAS: EFFECT OF TEMPERATURE AND FLOW RATE \\ M. Ángeles de la Rubia ${ }^{1 *}$, Mark Walker ${ }^{2}$, Sonia Heaven ${ }^{2}$, Charles J. Banks ${ }^{2}$, Rafael Borja $^{1}$
}

${ }^{1}$ Instituto de la Grasa (CSIC), Avda. Padre García Tejero 4, 41012 Sevilla (Spain).

${ }^{2}$ School of Civil Engineering and the Environment, University of Southampton, Southampton SO17 1BJ, UK.

* Corresponding author: M.A. De la Rubia, Instituto de la Grasa (CSIC),

Avda. Padre García Tejero, 4. 41012-Sevilla, Spain

(Tel.: +34-954689654; Fax: +34-954691262; E-mail address: arubia@ cica.es).

\begin{abstract}
Batch experiments to remove ammonia from food waste digestate were set up, and preliminary runs undertaken. These experiments were based on gas stripping in a heated column reactor; the effects of different temperatures $\left(35^{\circ} \mathrm{C}, 55^{\circ} \mathrm{C}\right.$ and $\left.70^{\circ} \mathrm{C}\right)$ and gas flow rates $\left(0.125,0.250\right.$ and $0.375 \mathrm{~L}_{\text {biogas }} \mathrm{L}_{\text {digestate }}{ }^{-1} \mathrm{~min}^{-1}$ ) were considered using biogas as the stripping gas. At $35^{\circ} \mathrm{C}$, an increase in the ammonia removal rate by approximately 4.5 times was observed when the flow rate increased from 0.125 to $0.375 \mathrm{~L}_{\text {biogas }} \mathrm{L}_{\text {digestate }}{ }^{-1} \mathrm{~min}^{-1}$. At 55 ${ }^{\circ} \mathrm{C}$, and flow rates of 0.250 and $0.375 \mathrm{~L}_{\text {biogas }} \mathrm{L}_{\text {digestate }}{ }^{-1} \mathrm{~min}^{-1}$, ammonia removal of 3.46 and $9.38 \% \mathrm{~d}^{-1}$, respectively, were achieved. The highest values of removal of ammonia were reached at $70{ }^{\circ} \mathrm{C}: 18.4$ and $10.4 \% \mathrm{~d}^{-1}$, for 0.250 and $0.375 \mathrm{~L}_{\text {biogas }} \mathrm{L}_{\text {digestate }}{ }^{-1} \mathrm{~min}^{-1}$ flow rates respectively.
\end{abstract}

Keywords: ammonia removal, anaerobic digestion, food waste, stripping

\section{INTRODUCTION}

The potential energy in food processing wastes is high because of the rich content of organic components (Digman and Kim, 2008). Although anaerobic digestion is a suitable and proven technology for stabilizing the organic fraction of municipal solid waste (OFMSW) (Hartman and Ahring, 2005; Benabdallah El Hadj et al., 2009), there are reports related to digesters operating entirely on source segregated food waste (SSFW) which suffer from process instability due to the composition of the feedstock with a high protein and fat content and possible nutrient deficiencies (Banks et al., 2008).

Anaerobic digestion effluents from organic wastes typically contain high concentrations of ammonium, phosphate, suspended solids, and persistent organic substrate. Therefore, there is a growing interest in this treatment due to its advantages in 
terms of energy and the fact that it produces fertilizer for recycling the nutrients to agricultural land (Salminen et al., 2001; Fricke et al., 2007). However, some issues remain regarding the use of digestates as fertilizer.

During anaerobic digestion of SSFW one of the operational problems is that nitrogen compounds enter the process mostly in the form of proteins. High concentrations of both ammonia and ammonium are produced due to the degradation of proteins and aminoacids and although anaerobic digestion can remain stable at high total ammoniacal nitrogen concentrations (i.e. 2-10 $\mathrm{g} \mathrm{L}^{-1}$ for poultry litter (Gangani Rao et al., 2008)), the result can be a significant reduction of biogas and methane production. Ammonium is an essential nutrient for microorganisms and it contributes to the stabilisation of the $\mathrm{pH}$ value in the reactor. This, in the form of ammonium bicarbonate buffers the system allowing it to operate even with high volatile fatty acid (VFA) concentrations. Free ammonia is known to be highly toxic, especially to acetoclastic methanogens. However, it has recently been found that the ammonium ion also inhibits biogas production during the anaerobic digestion of OFMSW by as much as $50 \%$ at high ammonium concentrations (3800 and $5600 \mathrm{mg} \mathrm{L}^{-1}$ under mesophilic and thermophilic conditions, respectively (Benabdallah El Hadj et al., 2009)). Furthermore, excess ammonia can inhibit not only the methanogenesis in anaerobic reactors (Nielsen and Angelidaki, 2008), but also the hydrolysis (PoggiVaraldo et al., 1997). In fact, hydrolysis of organic matter is the bottleneck for the degradation of complex organic matter found in SSFW. Therefore, to improve the hydrolytic and methanogenic steps, to optimize the biogas and methane yields and to obtain a properly digested effluent from domestic food waste that can be used as fertilizer, while avoiding nitrogen pollution in farming areas where high ammonia digestate has been used (Woli et al., 2004), a simple and effective process for removing ammonia is required.

Although there are many recent research works focusing on nitrogen removal from manure and wastewater, including biological denitrification (Wett and Rauch, 2003), ammonia-stripping (Lei et al., 2007), precipitation with phosphorus and magnesium as struvite (Uludag-Demirer et al., 2008), electrochemical conversion (Lei and Maekawa, 2007), microwave radiation (Lin et al., 2009) and ultrasound (Wang et al., 2008), there are no reports in the literature regarding in situ ammonia removal from SSFW digestate.

Ammonia stripping is a controlled process for the removal of ammonia from a solution which, combined with absorption, can remove and recover ammonia from wastes (Bonmatí and Flotats, 2003). The stripping process is relatively simple and stable if the $\mathrm{pH}$ and temperature remain constant. The procedure is unaffected by toxic compounds, that could disrupt the performance of a biological system (US EPA, 2000). Air stripping has been reported as an economical and efficient physical method for removing ammonia from poultry litter leachate (Gangagni Rao et al., 2008), and it can be carried out with or without chemicals to control the $\mathrm{pH}$ (Bonmatí and Flotats, 2003). Large additions of lime to increase the $\mathrm{pH}$ would increase the formation of calcium carbonate possibly resulting in severe maintenance problems (Liao et al., 1995).

The removal of $\mathrm{NH}_{3}-\mathrm{N}$ from different wastes by stripping is currently practised on supernatants after stabilization by anaerobic digestion (Bonmatí and Flotats, 2003; Lei et al., 2007). Chemical precipitation requires the addition of a reagent, which may introduce new pollutants to the process (Lin et al., 2009). Furthermore, the post-treatment of high strength leachate can be difficult and costly. Thus, the development of an in situ removal technique would be an attractive alternative, potentially offering both economic and environmental advantages. An ammonium removal process in the same system as anaerobic 
digestion, biogas stripping for instance, would be advantageous, as a notable level of nitrogen removal may be achieved resulting in relief of the inhibition problems known to the process. Furthermore, the biogas produced in the process could be used for stripping and purified during ammonia absorption using water and /or sulphuric acid.

The aim of this research was to study ammonia removal from SSFW digestate. The experiments are based on gas stripping in a heated column reactor; the effects of temperature and gas flow rate have been considered using biogas as the stripping gas. The removal of a small amount of ammonia could be sufficient to allow the biological process to operate more effectively. The results from these preliminary trials carried out in batch mode will be used for the selection of ammonia stripping conditions to be tested in continuous operation experiments.

\section{METHODS}

\section{Substrate}

Food waste digestate was collected from a commercial digester which treats SSFW from a mixture of commercial and municipal sources. The digestate, which contained a total ammonium concentration in the range of 6700-7700 $\mathrm{mg} \mathrm{L}^{-1}$, was homogenized with a commercial garbage grinder to an average size of below $4 \mathrm{~mm}$. Further characterization of digested food waste is outlined in Table 1.

A stripping process is usually applied to supernatant residues, different dosages of calcium hydroxide are added and after stirring and precipitation, the supernatants are stripped. In our case, since the addition of chemicals could disturb the anaerobic digestion process, none were used. Therefore, the digestate was directly treated by biogas stripping, with no pre-treatment before the stripping experiments.

Although the initial VFA concentration was different for each experiment $(17960 \pm$ $4640 \mathrm{mg}$ Acetic acid $\left.\mathrm{L}^{-1}\right) ; \mathrm{pH}(8.2 \pm 0.2)$ total ammonium concentration $\left(7270 \pm 346 \mathrm{mg} \mathrm{L}^{-}\right.$ $\left.{ }^{1}\right)$ and TKN $\left(9000 \pm 550 \mathrm{mg} \mathrm{L}^{-1}\right)$ were very similar in all cases. The differences for other parameters determined, such as total $\left(57.8 \pm 7 \mathrm{~g} \mathrm{Kg}^{-1}\right)$ and volatile $\left(41.2 \pm 6 \mathrm{~g} \mathrm{Kg}^{-1}\right)$ solids, can be explained because of the high heterogeneity of the raw material and also because steady-state conditions are not often reached in full-scale anaerobic digestion processes since plants are subjected to disturbances due to the variations of influent flow.

\section{Experimental set up}

The experimental set up of the reactor is outlined in Figure 1. A glass column (47.5 $\mathrm{cm}$ high $\times 10 \mathrm{~cm}$ internal diameter) with a thermally controlled water jacket, heated by a water circulator (Techne Circulator C-85 A) (4), was used for stripping in batch conditions. For each experiment $2 \mathrm{~kg}$ of source segregated food waste digestate (with a density of 1006 $\pm 13 \mathrm{mg} \mathrm{L}^{-1}$ ) was placed inside the column which was then sealed. The digestate was then subjected to a gas flow which was bubbled into the bottom of the column through a diffuser. The gas used for stripping was synthetic biogas $\left(\mathrm{CH}_{4}: \mathrm{CO}_{2}, 65: 35, \mathrm{BOC}\right.$, Guildford, UK).

After passing through the digestate, the biogas charged with ammonia was bubbled through a trap of $70 \mathrm{~mL}$ of deionised water (1) and then through two serial traps $(250 \mathrm{~mL}$ volume) of $40 \%$ sulphuric acid solution (2) to capture the ammonia, after which the biogas was pumped back into the bottom of the digester in a closed loop, using a peristaltic pump 
(Watson Marlow $601 \mathrm{~S}$ ) (3). A flowmeter (7) was placed between the peristaltic pump and the stripper column to control the biogas flow rate.

Between the deionised water trap (1) and the first sulphuric acid trap (2), a tedlar bag (8) with biogas (50\% of its $5 \mathrm{~L}$ of volume) was placed. This tedlar bag allowed for thermal expansion of the gas within the system as well as a store for the biogas produced during the assay or, as a reserve if more biogas was required for the system.

\section{Experimental Procedure}

Ammonia removal was performed by bubbling biogas through the digestate. Although the adsorption process was performed at room temperature, the stripping process was performed at temperatures of $35^{\circ} \mathrm{C}, 55^{\circ} \mathrm{C}$ and $70^{\circ} \mathrm{C}$ at gas flow rates of $0.125,0.250$ and $0.375 \mathrm{~L}_{\text {biogas }} \mathrm{L}_{\text {digestate }}{ }^{-1} \mathrm{~min}^{-1}$. The flow rates were chosen taking into account the common flow rates used in full scale anaerobic digesters for mixing. The stripping experiments were continued until no further ammonia removal occurred, and this happened when $\mathrm{pH}$ was lower than 7.5. The operational conditions of the different experiments carried out, including their duration, are summarized in Table 2.

The temperatures of $35^{\circ} \mathrm{C}$ and $55^{\circ} \mathrm{C}$ were chosen as they are the optimal mesophilic and thermophilic temperatures, respectively, at which anaerobic digesters commonly operate. $70{ }^{\circ} \mathrm{C}$ is the temperature used for pasteurisation. The main limiting factor for ammonia air stripping at $70{ }^{\circ} \mathrm{C}$ is the availability of a cheap thermal energy source. Most food waste treatment plants have a pasteurizer for deactivating the pathogens present in the waste. Consequently, ammonia biogas stripping could take place at this point of the treatment plant, meaning no investment would be necessary.

Samples were drawn from a port (5) near the bottom of the column, over the experimental period (at least once a day) and analyzed for ammonia, partial and total alkalinity and $\mathrm{pH}$ to determine their evolution.

Water and sulphuric acid solutions from the three ammonia traps were measured, sampled and analysed at the end of the experiment to determine the ammonia mass balance. Additionally, VFA, total Kjeldahl nitrogen (TKN), total solids (TS) and volatile solids (VS) were analysed on the digested food waste at the beginning and end of every experiment.

\section{Analytical Methods}

TS and VS were measured gravimetrically according to standard methods (APHA, 2005). Sieved samples were used for the determination of several parameters according to standard methods (APHA, 2005): $\mathrm{pH}$ was determined using a Jenway $3010 \mathrm{pH}-\mathrm{meter}$ (Jenway, London, UK), ammonia using the steam distillation method (APHA, 2005) and TKN using the digestion-steam distillation method (APHA, 2005). Partial (at pH 5.75) and total alkalinity (at $\mathrm{pH} 4.3$ ) were measured by $\mathrm{pH}$ titration according to Jenkins et al. (1983). VFA were analyzed using a Shimadzu GC-2010 (Shimadzu, Tokyo, Japan). A capillary column SG EBP 21 was used with helium as the carrier gas at a flow rate of $191 \mathrm{~mL} \mathrm{~min}^{-1}$. The GC oven temperature was programmed to rise from $60^{\circ} \mathrm{C}$ to $210{ }^{\circ} \mathrm{C}$ over 15 minutes, with a final hold time of 3 minutes. The temperatures of the injector and detector were 200 ${ }^{\circ} \mathrm{C}$ and $250{ }^{\circ} \mathrm{C}$, respectively. The sieved samples were first centrifuged at $14000 \mathrm{rpm}$ for 20 minutes, and the supernatant liquor was then acidified with formic acid (10\%). The samples were compared to standard solutions $\left(50,250\right.$ and $\left.500 \mathrm{mg} \mathrm{L}^{-1}\right)$ of acetic, propionic, isobutyric, n-butyric, iso-valeric, valeric, hexanoic and heptanoic acids. 
The ammonia removal efficiency (expressed in percentage) can be calculated by using the following expression:

Ammonia removalefficiency $(\%)=\frac{[\text { Ammonia }]_{i}-[\text { Ammonia }]_{f}}{[\text { Ammonia }]_{i}} * 100$

where $[\text { Ammonia }]_{i}$ is the initial ammonia concentration, and $[\text { Ammonia }]_{f}$ is the concentration of ammonia at the end of the experiment. Therefore, the ammonia removal rate is determined as follow:

$$
\text { Ammonia removalrate }\left(\% d^{-1}\right)=\frac{\text { Ammonia removalefficiency }(\%)}{\text { Operation time }(d)}
$$

\section{RESULTS AND DISCUSSION}

In order to achieve the maximum removal of ammoniacal nitrogen from digestate by biogas stripping, temperature and flow rate were considered. In all cases ammonia was removed from the digestate and captured in the water and acid traps, the results being summarized in Table 3.

The results were presented comparing assays developed at the same temperatures but different flow-rates. The variations of the ammonia concentrations with the operation time in the experiments performed are shown in Figures $2 \mathrm{a}, 3 \mathrm{a}$ and $4 \mathrm{a}$ at $35^{\circ} \mathrm{C}, 55^{\circ} \mathrm{C}$ and $70{ }^{\circ} \mathrm{C}$, respectively.

\section{Temperature: $35^{\circ} \mathrm{C}$}

Free ammonia concentration depends mainly on three parameters: the total ammonia concentration, temperature and $\mathrm{pH}$ (Hansen et al., 1998). It increases as the temperature and/or $\mathrm{pH}$ rise. At a high $\mathrm{pH}$, inhibition by VFA decreases because the acids become dissociated, whereas inhibition by ammonia increases as the free form becomes prevalent (Fricke et al., 2007).

As can be seen in Figure 2, at $35^{\circ} \mathrm{C}$ the $\mathrm{pH}$ was relatively constant and, for the three flow rates studied, higher than 8 , although an initial increase was observed. In acidic and neutral media ammonia nitrogen occurs as $\mathrm{NH}_{4}{ }^{+}$. In basic solution, non-volatile $\mathrm{NH}_{4}{ }^{+}$is converted to volatile $\mathrm{NH}_{3}$. Therefore, at $\mathrm{pH} 8$ the volatilization of ammonia is slower than at a higher $\mathrm{pH}$ (Malpei et al., 2008). However a continuous, albeit low, ammonia removal rate was achieved.

At $35^{\circ} \mathrm{C}$ the ammonia removal rate was lower than in the experiments at higher temperatures. The rates of removal at both 0.125 and $0.250 \mathrm{~L}_{\text {biogas }} \mathrm{L}_{\text {digestate }}{ }^{-1} \mathrm{~min}^{-1}$ were similar and the concentrations of ammonia at the end of the experiments ( 200 hours) were 6370 and $5950 \mathrm{mg} \mathrm{N}-\mathrm{NH}_{3} \mathrm{~L}^{-1}$, respectively. However, at the increased flow rate, 0.375 $\mathrm{L}_{\text {biogas }} \mathrm{L}_{\text {digestate }}{ }^{-1} \mathrm{~min}^{-1}$, the ammonia removal rate was approximately 4 times greater, meaning that after 54 hours the ammonia concentration was $6090 \mathrm{mg} \mathrm{N}-\mathrm{NH}_{3} \mathrm{~L}^{-1}$. This demonstrates the importance of the flow rate in the removal process, as was reported previously (Liao et al., 1995). The final ammonia concentration at the flow rate of 0.375

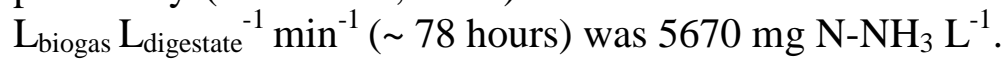

In all cases both partial and total alkalinity decreased during the experiments owing to the removal of ammonia and the precipitation of carbonates which contribute to this measurement (Cheung et al., 1997). 
Although the removal rates were so low as to remove just $15 \%$ of the ammonia present in the residue over almost 200 hours, it should not be forgotten that the residue was not treated with lime to increase the $\mathrm{pH}$, and modest gas flow rates were used when compared with other researches; Liao et al. (1995) used between 15-30 $\mathrm{L}_{\text {air }} \mathrm{L}_{\text {swine manure }}$ supernatant ${ }^{-1} \mathrm{~min}^{-1}$, while Lei et al. (2007) utilized from 3 to $10 \mathrm{~L}_{\text {air }} \mathrm{L}^{-1} \mathrm{~min}^{-1}$ to strip the ammonia from the kitchen garbage supernatant. Furthermore, in a continuous anaerobic digester treating food waste, retention times of 50-100 days are typical, meaning that the maintenance of an ammonia concentration at $50 \%$ of the natural steady-state concentration only requires an ammonia removal rate of $0.5 \%-1 \%$ of the total per day. Therefore, with respect to an in situ process, the rates obtained here may be suitable.

Working with liquid swine manure, Liao et al. (1995) obtained ammonia removal efficiencies of $80 \%$ approx. after around $250 \mathrm{~h}$ of treatment operating at a $\mathrm{pH}$ of 9.3 and a flow rate of $15 \mathrm{~L}_{\text {air }} \mathrm{L}_{\text {digestate }}{ }^{-1} \mathrm{~min}^{-1}$, a considerably higher flow rate than those used in the present work. Furthermore, other conditions were very different from the present work in that the $\mathrm{pH}(\sim 8)$ was also much lower and the initial TS much higher $(>50 \%)$.

\section{Temperature: $55^{\circ} \mathrm{C}$}

At $55{ }^{\circ} \mathrm{C}$ free ammonia will always be higher than at $35{ }^{\circ} \mathrm{C}$, as was reported elsewhere (Lin et al., 2009).

For the three experiments performed at this temperature, the $\mathrm{pH}$ trend was similar; an initial increase, probably caused by equilibrating carbonates between the biogas and digestate, followed by a decrease, showing the effect of ammonia removal (Bonmatí and Flotats, 2003).

The results from ammonia removal at $55^{\circ} \mathrm{C}$ and $0.125 \mathrm{~L}_{\text {biogas }} \mathrm{L}_{\text {digestate }}{ }^{-1} \mathrm{~min}^{-1}$, shown in Figure 3a, did not follow the trends of the other experimental results; the ammonia initially decreased and then increased to a higher concentration. This could be explained by the low ammonia removal rate due to the decrease in $\mathrm{pH}$ (Figure 3b) which reduced ammonium volatility by shifting its dissociation reaction towards the ionic form, as was also observed by Bonmatí and Flotats (2003). It was thought that although there was a greater concentration of free ammonia at the higher temperature of $55^{\circ} \mathrm{C}$ (when compared to $35^{\circ} \mathrm{C}$ ), it is possible that the flow rate was too low to remove an appreciable amount of ammonia. An increased gas flow rate increases the gas-liquid surface area, which in turn controls the amount of $\mathrm{NH}_{3}$ diffused from water (Lei et al., 2007). After this anomalous result the flow rate was increased to $0.375 \mathrm{~L}_{\text {biogas }} \mathrm{L}_{\text {digestate }}{ }^{-1} \mathrm{~min}^{-1}$ for 30 minutes, and the final concentration of ammonia was approximately $5700 \mathrm{mg} \mathrm{N}-\mathrm{NH}_{3} \mathrm{~L}^{-1}$ (data not shown in the Figure). This suggests that there could be potential for an ammonia stripping process under continuous $\mathrm{pH}$ control to change the flow rate.

The two experiments at higher flow rates showed similar trends to those at $35{ }^{\circ} \mathrm{C}$. The ammonia removal rate increases with gas flow rate, stabilising at similar end concentrations $\left(5740 \mathrm{mg} \mathrm{L}^{-1}\right.$ at $0.250 \mathrm{~L}_{\text {biogas }} \mathrm{L}_{\text {digestate }}{ }^{-1} \mathrm{~min}^{-1}$ and $6160 \mathrm{mg} \mathrm{L}^{-1}$ at $0.375 \mathrm{~L}_{\text {biogas }}$ $\mathrm{L}_{\text {digestate }}{ }^{-1} \mathrm{~min}^{-1}$ ). The $\mathrm{pH}$ trend showed, as before, an initial increase followed by a decrease. However, in these cases the final $\mathrm{pH}$ was lower, dropping to around 7.5 in both experiments. Observation of the data shown in Figure 3 suggests that the decrease in $\mathrm{pH}$ to around 7.5-8 prevents further ammonia removal, which is in line with the findings of Lin et al. (2009).

Alkalinity decreased with time which led to a decreased $\mathrm{pH}$. The high VFA concentrations influenced this drop. 


\section{Temperature: $70^{\circ} \mathrm{C}$}

Operation of the stripping process at $70{ }^{\circ} \mathrm{C}$ resulted in the greatest ammonia removal rates as shown in Figure 4. Indeed the higher the temperature and $\mathrm{pH}$, the higher the free ammonia fraction. However, a difference relative to the previous results should be pointed out - the increased flow rate $\left(0.375 \mathrm{~L}_{\text {biogas }} \mathrm{L}_{\text {digestate }}{ }^{-1} \mathrm{~min}^{-1}\right)$, although resulting in the fastest initial ammonia removal, apparently removed less ammonia over the experimental period than the lower flow rate studied in this case $\left(0.250 \mathrm{~L}_{\text {biogas }} \mathrm{L}_{\text {digestate }}{ }^{-1} \mathrm{~min}^{-1}\right)$.

At $70{ }^{\circ} \mathrm{C}$ and a flow rate of $0.375 \mathrm{~L}_{\text {biogas }} \mathrm{L}_{\text {digestate }}{ }^{-1} \min ^{-1}$ the $\mathrm{pH}$ did not show the trend of an initial increase followed by a gradual decrease. Temperature affects the chemical equilibrium between substances leading to a new chemical equilibrium that modifies the $\mathrm{pH}$ (Bonmatí and Flotats, 2003) and in this case the $\mathrm{pH}$ decreased from the start of the experiment because of the high ammonia removal rate. To be specific, the $\mathrm{pH}$ decreased to around 6.5 in less than 20 hours. This then prevented further ammonia removal since at this $\mathrm{pH}$ the ammonium ion prevails in solution, even at a high temperature, as has been stated by Fricke et al. (2007) and as was seen in the experiments at $35^{\circ} \mathrm{C}$ and $55^{\circ} \mathrm{C}$ (see Figure 4). Another effect which comes into play at a high temperature is the evaporation of the liquid in the digestate. Over the experimental period at the highest temperature and flow rate approximately $25 \%$ of the digestate content ( 0.5 litres) was lost as evaporated moisture. This meant that although ammonia was removed, the concentration in the digestate remained the same or even increased as can be seen in Figure 4. Mass balance is very useful to justify the real ammonia evolution in case $\left(70{ }^{\circ} \mathrm{C}\right.$ and a flow rate of $0.375 \mathrm{~L}_{\text {biogas }} \mathrm{L}_{\text {digestate }}{ }^{-1} \mathrm{~min}^{-1}$ ), where a lot of water was evaporated. Taking into account the initial and final ammonia concentrations as well as the initial and final mass of SSFW, the initial mass of ammonia in this experiment was $14640 \mathrm{~g} \mathrm{~N}^{-\mathrm{NH}_{3}}$ and the final $9020 \mathrm{~g} \mathrm{~N}-$ $\mathrm{NH}_{3}$ with a mass unaccounted of $5.5 \%$. Therefore, an important ammonia removal was reached.

This defeats the purpose of removing ammonia in order to reduce 'in reactor' concentrations. Consequently, temperature is a crucial factor in the stripping process as was also reported elsewhere (Poulopoulos et al., 2005).

Alkalinity also decreased in all treatments (Figure 4d). The formation and precipitation of salts (Cheung et al., 1997) and/or $\mathrm{CO}_{2}$ stripping (Collivignarelli et al., 1998) may explain this reduction. This loss of the buffering capacity during the stripping process together with the high VFA concentrations resulted in a decrease in $\mathrm{pH}$. Moreover, the low VFA volatility at these pHs together with water evaporation, led to a slight increase in their concentration.

The conditions at $70{ }^{\circ} \mathrm{C}$ and $0.250 \mathrm{~L}_{\text {biogas }} \mathrm{L}_{\text {digestate }}{ }^{-1} \mathrm{~min}^{-1}$ showed a greater removal of ammonia over the experimental period and a greater overall removal rate compared to the higher biogas flow rate. This could be due to the fact that the removal of ammonia is initially slower and therefore did not lead to a rapid destabilisation in $\mathrm{pH}$ which in turn allows greater ammonia removal. However, this experiment had an initial VFA concentration of $\sim 10,000 \mathrm{mg} \mathrm{L}^{-1}$ as compared with $\sim 17,000 \mathrm{mg} \mathrm{L}^{-1}$ (see Table 1) in the other experiments which could explain the stable $\mathrm{pH}$ despite a large proportion of ammonia removal. This in itself is an interesting result since, if the ammonia stripping process was being used as a preventive measure for the build-up of VFA in a food waste digestate, the VFA concentration would in general be lower than $10,000 \mathrm{mg} \mathrm{L}^{-1}$. If this result holds for all 
flow/temperature combinations then ammonia removal would be more effective on a time basis in a 'healthy' digester.

The variation in temperature and flow rate researched here leads to a change in the ammonia removal rate of one order of magnitude between $\sim 1.8 \%-18.9 \%$ day $^{-1}$ under these conditions of high VFA concentrations $\left(\sim 17,000 \mathrm{mg} \mathrm{L}^{-1}\right)$ and ammonia $\left(\sim 7000 \mathrm{mg} \mathrm{L}^{-1}\right)$.

\section{Ammonia mass balance}

The ammonia mass balance showed that an average of $5 \%$ of the ammonia was not accounted for. Bonmatí and Flotats (2003) reported imbalances of between $6 \%$ and $16 \%$ when performing pig slurry air stripping assays. They attributed this to experimental error because ammonia was not detected in the second ammonia trap in any of the experiments. In the current work ammonia was detected in the water trap and also in the first sulphuric acid trap, but not in the second sulphuric acid trap.

The $5 \%$ of unaccounted for ammonia could be attributed to a number of causes including loss during sampling, leaks, vaporised ammonia at the end of the experiment and other experimental errors.

The concentration of TKN was also determined in all experiments and there were no differences in the relationship between TKN and total ammonium nitrogen during the experimental period meaning that no other forms of nitrogen were removed, as was also reported by Lin et al. (2009).

From the results of these batch experiments it is thought that biogas stripping is an interesting option for the effective removal of ammonia in an anaerobic digestion process, although further work is necessary. Future experiments will look into the possibility of stripping ammonia in a side stream process in a semi-continuous anaerobic digester. Digesters will be analysed for ammonia, alkalinity, biogas production and composition, $\mathrm{pH}$ and VFA in order to assess the effectiveness of ammonia stripping with regard to maintaining a healthy anaerobic process (e.g. no excessive build-up of VFA).

\section{CONCLUSIONS}

Ammonia removal from food waste digestate was possible using biogas stripping. Increased temperatures and gas flow rates both increased the rate of removal. A rapid ammonia removal caused a rapid drop in $\mathrm{pH}$, which could hinder further ammonia removal.

At $35{ }^{\circ} \mathrm{C}$ there was slow steady removal of ammonia $\left(1.8-8.3 \% \mathrm{~d}^{-1}\right)$ and little variation in $\mathrm{pH}$. At $55{ }^{\circ} \mathrm{C}$, a low flow rate is not enough to remove the free ammonia fraction, causing an increase in the concentration of ammonia. Finally, at $70{ }^{\circ} \mathrm{C}$ the apparent ammonia removal rate decreased with time (from 18.9 to $10.4 \% \mathrm{~d}^{-1}$ at 0.250 and $0.375 \mathrm{~L}_{\text {biogas }} \mathrm{L}_{\text {digestate }}{ }^{-1} \mathrm{~min}^{-1}$, respectively) due to a higher rate of water evaporation in relation to the rate of ammonia stripping.

\section{Acknowledgements}

The authors wish to express their gratitude to the Spanish Ministry of "Educación y Ciencia" (Programa Nacional de Movilidad de Recursos Humanos del Plan nacional de ID+I 2008-2011) for providing financial support and to "Programa Juan de la Cierva del Ministerio de Ciencia e Innovación para la contratación de jóvenes doctores”. Additionally, the authors would also like to acknowledge additional financial support from the Department of Farming and Rural Affairs (Defra), UK. 


\section{REFERENCES}

- APHA-AWWA-WPCF, 2005. Standard Methods for the Examination of Water and Wastewater. $21^{\text {st }}$ edition, American Public Health Association, American Water Works Association, Water Environment Federation, Washington DC, USA.

- Banks, C., Chesshire, M., Stringfellow, A., 2008. A pilot-scale comparison of mesophilic and thermophilic digestion of source segregated domestic food waste. Water Sci. Technol. 58(7), 1475-1481.

- Benabdallah El Hadj, T., Astals, S., Galí, A., Mace, S., Mata-Álvarez, J., 2009. Ammonia influence in anaerobic digestion of OFMSW. Water Sci. Technol. 59(6), 1153-1158.

- Bonmatí, A., Flotats, X., 2003. Air stripping of ammonia from pig slurry: characterisation and feasibility as a pre- or post-treatment to mesophilic anaerobic digestion. Waste Manage. 23, 261-272.

- $\quad$ Cheung, K.C., Chu, L.M., Wong, M.H., 1997. Ammonia stripping as a pretreatment for landfill leachate. Water Air Soil Pollut. 94, 209-221.

- Collivignarelli, C., Bertanza, G., Baldi, M., Avezzù, F., 1998. Ammonia stripping from MSW landfill leachate in bubble reactors: Process modeling and optimization. Waste Manage. Res. 16 (5), 455-466.

- Digman, B., Kim D-S., 2008. Review: alternative energy from food processing wastes. Environ. Prog. 27(4), 524-537.

- Fricke, K., Santen, H., Wallmann, R., Hüttner, A., Dichtl, N., 2007. Operating problems in anaerobic digestion plants resulting from nitrogen in MSW. Waste Manage. 27, 30-43.

- Gangagni Rao, A., Sasi Kanth Reddy, T., Surya Prakash, S., Vanajakshi, J., Joseph, J., Jetty, A., Rajashekhara Reddy, A., Sarma, P.N., 2008. Biomethanation of poultry litter leachate in UASB reactor coupled with ammonia stripper for enhancement of overall performance. Bioresour. Technol. 99, 8679-8684.

- Hansen, K.H., Angelidaki, I., Ahring, B.K., 1998. Anaerobic digestion of swine manure: inhibition by ammonia. Water Res. 32(1), 5-12.

- Hartmann, H., Ahring, B.K., 2005. A novel process configuration for anaerobic digestion of source-sorted household waste using hyper-thermophilic posttreatment. Biotechnol. Bioeng. 90(7), 830-837.

- Jenkins, S.R., Morgan J.M., Sawyer, C.L., 1983. Measuring anaerobic sludge digestion and growth by a simple alkalimetric titration. J. Water Pollut. Control Fed. 55 (5), 448-453.

- Lei, X, Sugiura, N., Feng, C., Maekawa, T., 2007. Pretreatment of anaerobic digestion effluent with ammonia stripping and biogas purification. J. Hazard. Mater. 145, 391-397.

- Lei, X., Maekawa, T., 2007. Electrochemical treatment of anaerobic digestion effluent using a Ti/Pt- $\mathrm{IrO}_{2}$ electrode. Bioresour. Technol. 98, 3521-3525.

- Liao, P.H., Chen, A., Lo, K.V., 1995. Removal of nitrogen from swine manure wastewaters by ammonia stripping. Bioresour. Technol. 54, 17-20.

- Lin L., Yuan, S., Chen, J., Xu, Z., Lu, X.., 2009. Removal of ammonia nitrogen in wastewater by microwave radiation. J. Hazard. Mater. 161, 1063-1068. 
- Malpei, F., Ficara, E., Canziani, R., 2008. Nitrogen removal from digestate: conventional and advanced Technologies, in: Adani, F., Schievano, A., Boccasile, G. (Eds.), Anaerobic digestion: Opportunities for Agriculture and Environment. Ed. University of Milan, pp. 113-127.

- Nielsen, H.B., Angelidaki, I., 2008. Strategies for optimizing recovery of the biogas process following ammonia inhibition. Bioresour. Technol. 99, 7995-8001.

- Poggi-Varaldo, H.M., Rodríguez-Vázquez R., Fernández-Villagómez, G., EsparzaGarcía, F., 1997. Inhibition of mesophilic solid-substrate digestion by ammonia nitrogen. Appl. Microbiol. Biotechnol. 47(3), 284-291.

- Poulopoulos, S.G., Voutsas, E.C., Grigiropoupou, H.P., Philippopoulos, C.J., 2005. Stripping as a pre-treatment process of industrial oily wastewater. J. Hazard. Mater. B117, 135-139.

- Salminen, E., Rintala, J. Härkönen, J., Kuitunen, M., Högmander, H., Oikari, A., 2001. Anaerobically digested poultry slaughterhouse wastes as fertilizer in agriculture, Bioresour. Technol. 78, 81-88.

- Uludag-Demirer, S., Demirer, G.N., Frear, C., Chen, S., 2008. Anaerobic digestion of dairy manure with enhanced ammonia removal. J. Environ. Manage. 86, 193200.

- US Environmental Protection Agency, 2000. Wastewater Technology Fact Sheet Ammonia Stripping. 832-F-00-019.

- Wang, S., Wu, X., Wang, Y., Li, Q., Tao, M., 2008. Removal of organic matter and ammonia nitrogen from landfill leachate by ultrasound. Ultrason. Sonochem. 15, 933-937.

- Wett, B., Rauch, W., 2003. The role of inorganic carbon limitation in biological nitrogen removal of extremely ammonia concentrated wastewater. Water Res. 37, $1100-1110$.

- Woli, K.R., Nagumo, T., Kuramochi, K., Hatano, R., 2004. Evaluating river water quality through land use analysis and $\mathrm{N}$ budget approaches in livestock farming areas. Sci. Total Environ. 329, 61-74.

Table 1. Characterization of the source segregated digested food waste used in the stripping experiments

\begin{tabular}{lllll}
\hline Parameter & Unit & Min & Max & Mean \\
\hline
\end{tabular}




\begin{tabular}{lllll}
\hline TS & $\mathrm{g} \mathrm{Kg}^{-1}$ & 50.4 & 67.6 & 57.8 \\
VS & $\mathrm{g} \mathrm{Kg}^{-1}$ & 33.9 & 51.3 & 41.2 \\
$\mathbf{N H}_{3}$-N & $\mathrm{mg} \mathrm{L}^{-1}$ & 6755 & 7735 & 7170 \\
TKN & $\mathrm{mg} \mathrm{L}^{-1}$ & 8260 & 9540 & 8954 \\
pH & - & 8.0 & 8.5 & 8.2 \\
Partial Alkalinity & $\mathrm{mg} \mathrm{CaCO}_{3} \mathrm{~L}^{-1}$ & 6375 & 14250 & 9469 \\
Total Alkalinity & $\mathrm{mg} \mathrm{CaCO}_{3} \mathrm{~L}^{-1}$ & 20875 & 27000 & 24000 \\
VFA & $\mathrm{g} \mathrm{Acetic} \mathrm{acid} \mathrm{L}^{-1}$ & 9.8 & 23.8 & 18.0 \\
\hline
\end{tabular}

Table 2. Operational conditions of the different assays developed

\begin{tabular}{lllll}
\hline Assay & $\begin{array}{l}\text { Temperature } \\
\left({ }^{\mathbf{o}} \mathbf{C}\right)\end{array}$ & $\begin{array}{l}\text { Flow rate } \\
\left(\mathbf{L}_{\text {biogas }} \mathbf{L}_{\text {digestate }} \mathbf{- 1}^{\mathbf{1}} \mathbf{m i n}^{-\mathbf{1}}\right)\end{array}$ & $\begin{array}{l}\text { Initial } \\
\mathbf{p H}\end{array}$ & $\begin{array}{l}\text { Duration } \\
\text { experiment (h) }\end{array}$ \\
\hline B1 & 35 & 0.125 & 8.1 & 196 \\
B2 & 35 & 0.250 & 8.1 & 194 \\
B3 & 35 & 0.375 & 8.3 & 78 \\
B4 & 55 & 0.125 & 8.2 & 72 \\
B5 & 55 & 0.250 & 7.9 & 104 \\
B6 & 55 & 0.375 & 8.1 & 46 \\
B7 & 70 & 0.250 & 8.3 & 56 \\
B8 & 70 & 0.375 & 8.6 & 29 \\
\hline
\end{tabular}

Table 3 Summary of the ammonia removal rates

\begin{tabular}{llll}
\hline $\begin{array}{l}\text { Temperature } \\
\left({ }^{\mathbf{0}} \mathbf{C}\right)\end{array}$ & $\begin{array}{l}\text { Flow rate } \\
\left(\mathbf{L}_{\text {biogas }} \mathbf{L}_{\text {digestate }} \mathbf{- 1}_{\mathbf{m i n}} \mathbf{- 1}\right)\end{array}$ & $\begin{array}{l}\text { Ammonia } \\
\text { removal }(\%)\end{array}$ & $\begin{array}{l}\text { Ammonia removal } \\
\text { rate }\left(\% \mathbf{d}^{-\mathbf{1}}\right)\end{array}$ \\
\hline 35 & 0.125 & 15 & 1.84 \\
35 & 0.25 & 15 & 1.86 \\
35 & 0.375 & 27 & 8.31 \\
55 & 0.125 & $\mathrm{~N} / \mathrm{A}$ & N/A \\
55 & 0.25 & 15 & 3.46 \\
55 & 0.375 & 18 & 9.39 \\
70 & 0.25 & 44 & 18.9 \\
70 & 0.375 & 13 & 10.4 \\
\hline
\end{tabular}

N/A: not applicable 
- (1) Water trap

- (2) Sulphuric traps

- (3) Peristaltic pump

- (4) Thermostatic bath

- (5) Sample port

- (6) Reactor

- (7) Flowmeter

- (8) Tedlar bag

. . Gas circuit

Water circuit

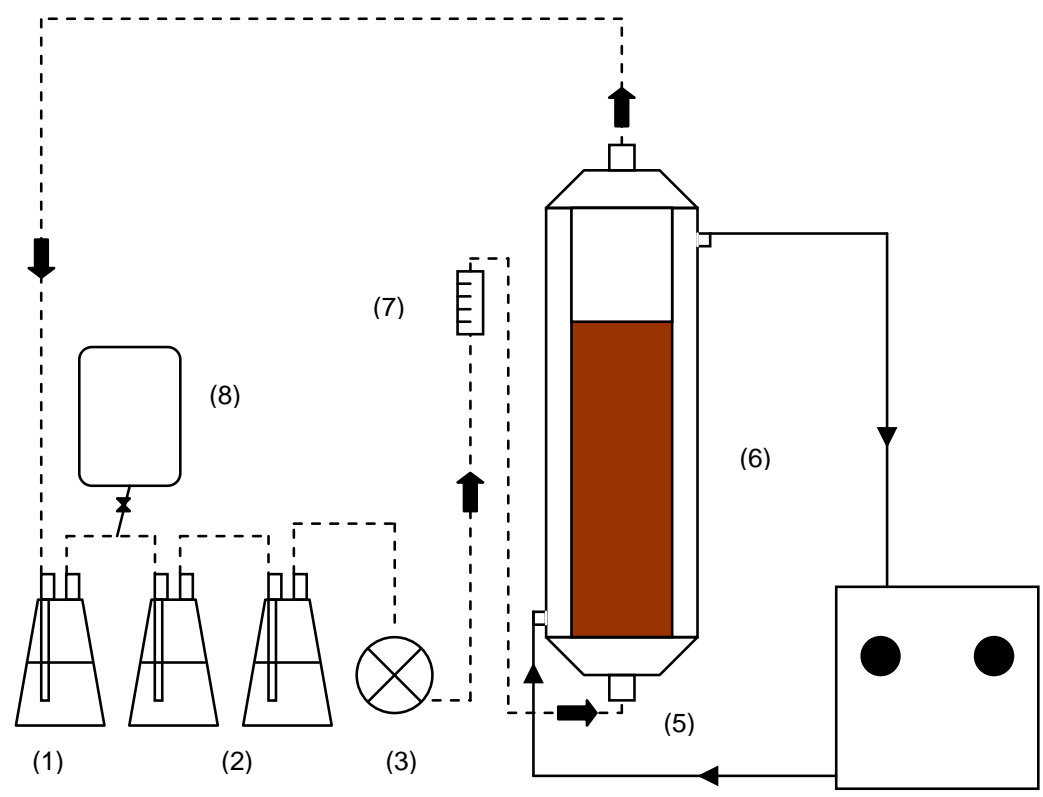

(4)

Figure 1. Schematic representation of the experimental system 

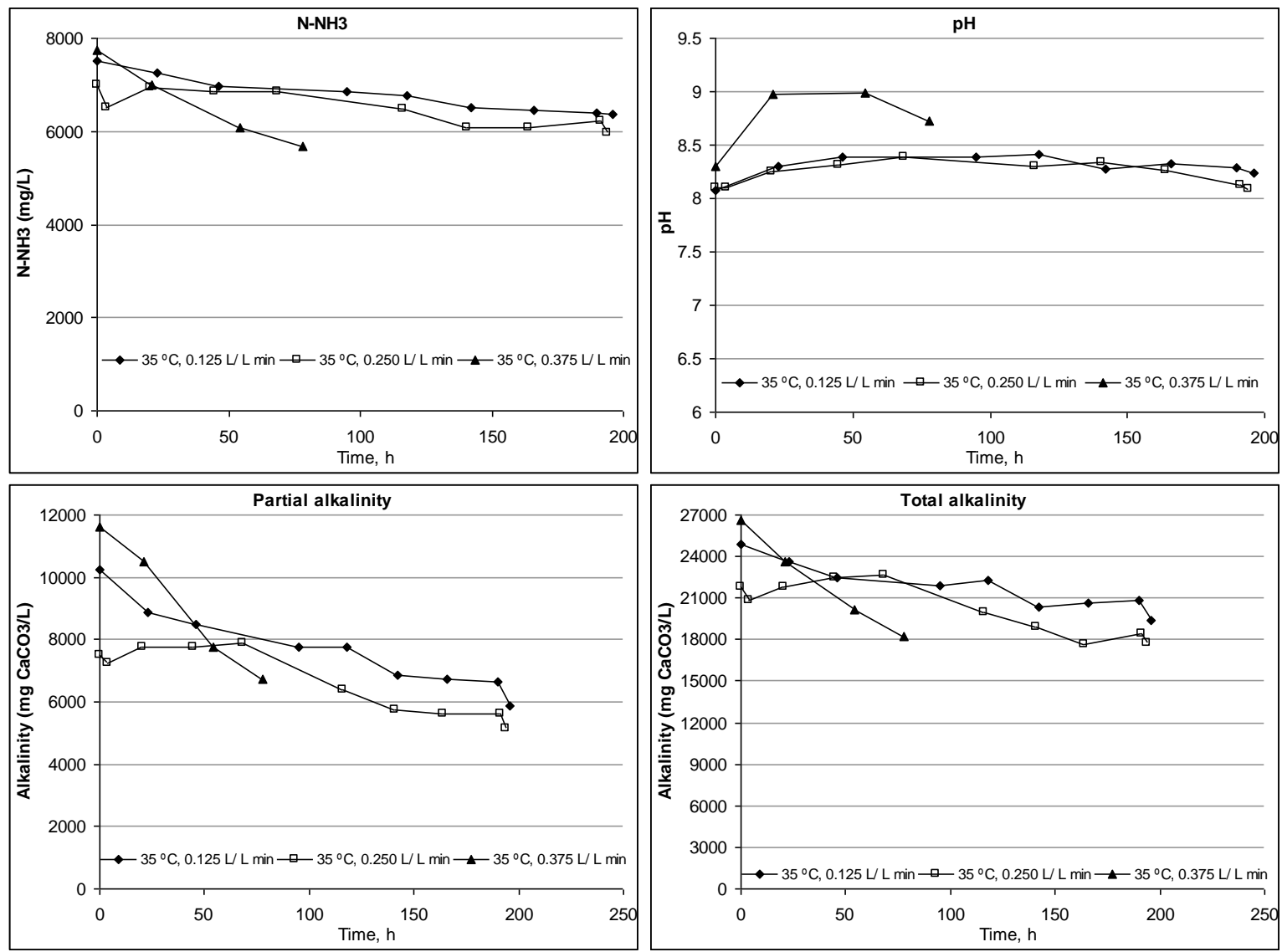

Figure 2. Ammonia stripping using biogas at $35^{\circ} \mathrm{C}$. Evolution of: (a) Ammonia nitrogen expressed as $\mathrm{mg} \mathrm{N}-\mathrm{NH}_{3} \mathrm{~L}^{-1}$, (b) $\mathrm{pH}$, (c) Partial alkalinity expressed as $\mathrm{mg}$ $\mathrm{CaCO}_{3} \mathrm{~L}^{-1}$, and (d) Total alkalinity expressed as $\mathrm{mg} \mathrm{CaCO}_{3} \mathrm{~L}^{-1}$ 

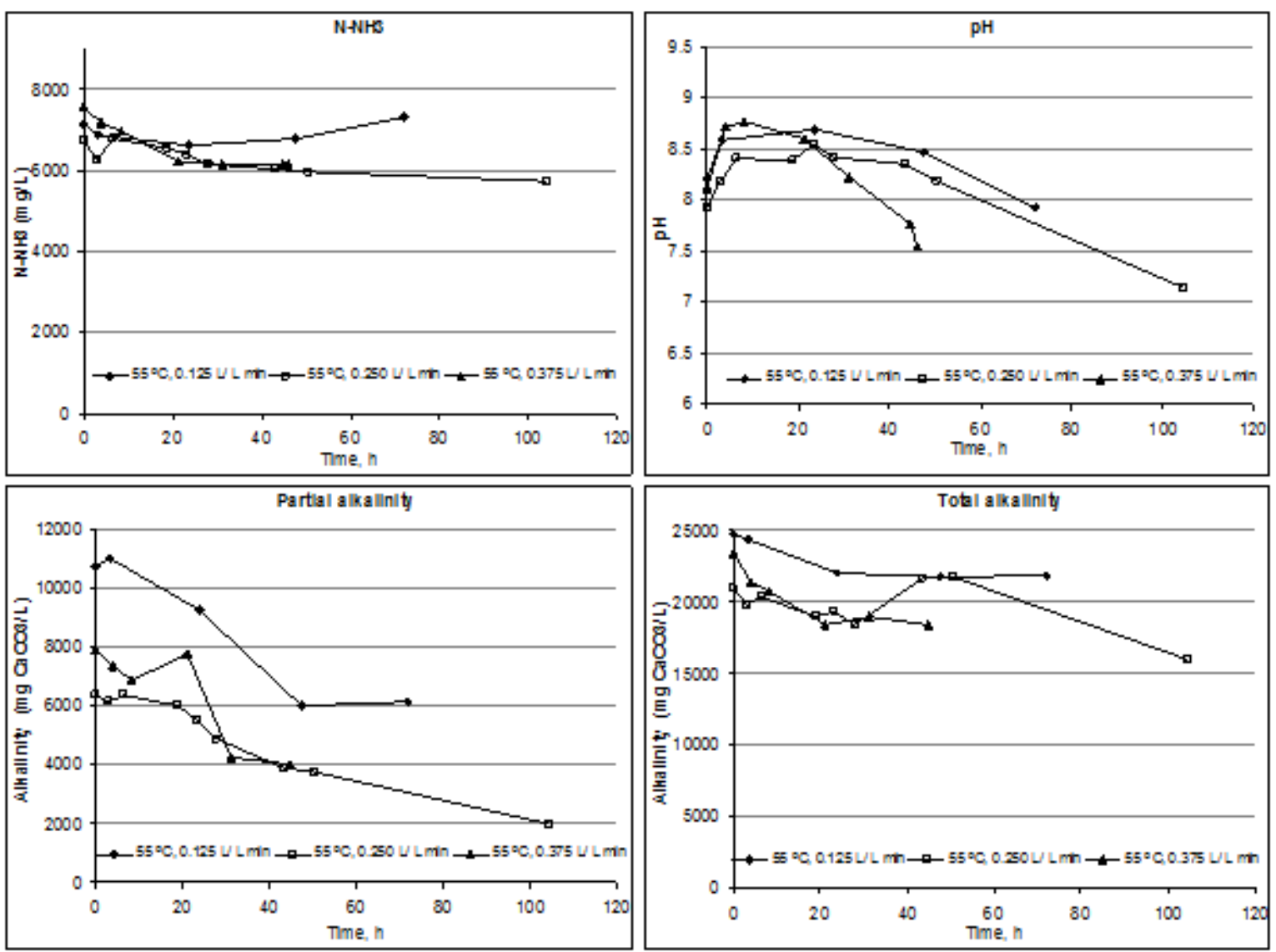

Figure 3. Ammonia stripping using biogas at $55^{\circ} \mathrm{C}$. Evolution of: (a) Ammonia nitrogen expressed as mg N-NH3 L-1, (b) pH, (c) Partial alkalinity expressed as mg CaCO3 L-1, and (d) Total alkalinity expressed as mg CaCO3 L-1. 

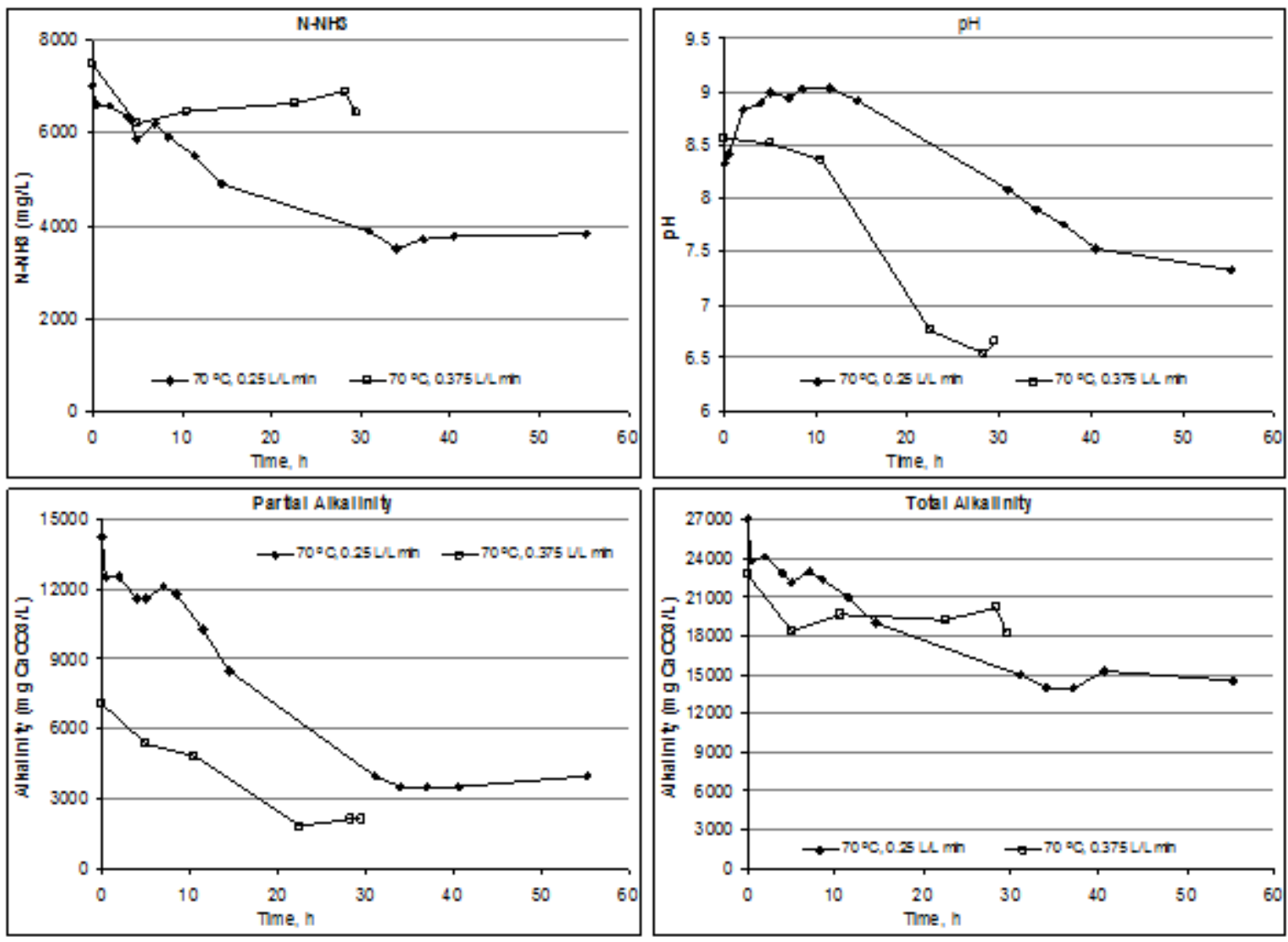

Figure 4. Ammonia stripping using biogas at $70^{\circ} \mathrm{C}$. Evolution of: (a) Ammonia nitrogen expressed as $\mathrm{mg} \mathrm{N}$-NH3 $\mathrm{L}-1$, (b) $\mathrm{pH}$, (c) Partial alkalinity expressed as $\mathrm{mg}$ $\mathrm{CaCO} 3 \mathrm{~L}-1$, and (d) Total alkalinity expressed as mg CaCO3 L-1. 